\title{
臭化ベンジルによる核置換 $\boldsymbol{N}, \boldsymbol{N}$-ジメチル アニリンの四級化反応122
}

(1972 年 1 月 17 日受理)

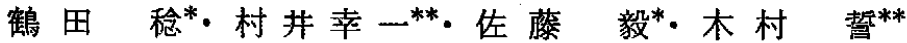

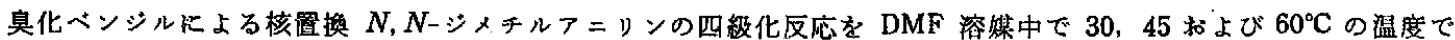
試み，速度論的測定を行なった。直線自由エネルギ一网係の成立を検討し，反応性に和上ぼす圈換基効果を明らかに した。

実験結果によれば，速度定数 $k$ 㤌 $0.203 \sim 78.1 \times 10^{-4} l \cdot \mathrm{mol}^{-1} \cdot \mathrm{sec}^{-1}\left(45^{\circ} \mathrm{C}\right)$ で，反応は睓換基の電子供与性と々も にいちじるしく促進された。活性化ェネルギーE 6.5 10 kcal $/ \mathrm{mol}$, 活性化ェントロピー $4 S^{*}-42 \sim-60 \mathrm{e} . \mathrm{u}$. の

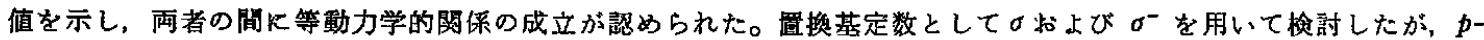
ホルミル, $p$-ベンゾイル, $p$-ニトロ, $p$-メトキシおよび $m$-水酸基では Hammett 式から偏倚するのが認められた。 の値を用いた Hammett 式は $\log k=-1.92 \sigma-2.874\left(45^{\circ} \mathrm{C}\right)$ であらわされた。

偏倚の原因は，これら厧換基と反応中心との直接共役効果および㯰換基に対するDMF の溶媒奻果によるるのであ ることを教察した。

\section{1 楮言}

ハロゲン化ベンジルによるジメチルアニリンの四級化反応は， 建染染料ロイ二塩合成に関連して工業的にす重要なるのであるが 他方，メンシュトキン反応の一例として，有機反応論の立場から 興味むる研究対象と考えられる。反応関与する武桬の構造と 反応性阅する研究は，まず直線自由エネルギー関係の一つとし て知られる Hammett 䐓について険討が試文られたが，核置換へ ソジル化合物に関しては，基質の反応におよぼす因子が椱雄であ るため，Hammett 則関倸はよい直線性を与えないことが報告さ れているふ。一方，求核試薬である核圆換 $N, N$-ジメキルアニリ ソに関しては，低級ハロゲン化アルキルによる四級化反度に抏い

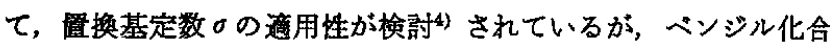
物との反応については少数の部分的な報告らがみられるだけで, いまた統一的な解釈はなされていない。

著者らは，非プロトソ溶媒中での臭化ベンジルによる圆換 $N, N$-ジメチルアニリンの四級化反応について速度諭的澌定を行 ない, 直線自由エネルギー関係の成否を検討して，反応性に扣上 ぼす置換基効果について考察を試みた。

\section{2 実験}

\section{1 試 料}

実験に供した臭化ベンジルは市肘特級陚薬を精留して用いた。 $p-N, N$-ジメチルアニシジン $\left(\mathrm{mp} 47^{\circ} \mathrm{C}\right)^{6)}, m$-ブロモジメチルア

1）この報文を“第三級アミンの四級化化関する動力学的研卶 (第 7 報)”とする。

2）前報(第 6 報)，木村 彗，村井幸一，越前悠二，油化学， 20, 883(1971).

* 秋田工業高等專門学校工業化学科, 秋田市飯鳥

** 秋田大学鉣山学部然料化学科, 秋田市手形

3) C. G. Swain, W. P. Langsdorf, J. Amer, Chem. Soc., 73, 2813 (1951).

4) J. B. Rosell, J. Chem. Soc., 1963, 5183.
ニリン $\left(\mathrm{bp} 118 \sim 119^{\circ} \mathrm{C} / 8 \mathrm{mmHg}\right)^{7)}$ は相当する置掺アニリンの硫 酸ジメチルによる $N$ ーアルキル化により合成した。pージメチルア ミノベンゾフェノン $\left(\mathrm{mp} 91^{\circ} \mathrm{C}\right)^{8)}$ はベンズアニリドとジメチルア ニリンの縮合により, $p$-キオシアノジメチルアニリン $\left(\mathrm{mp} 74^{\circ} \mathrm{C}\right)^{9)}$ はジメチルアニリンに莫素とチオシアン酸アンモンを反灾させて それぞれ合成した。これらはいずれるガスクロマトグラフィーに より単一成分であることを確かめて使用した。

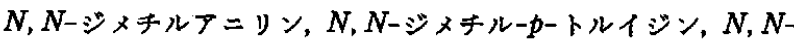

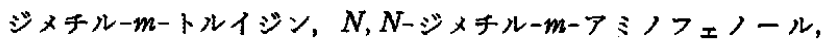

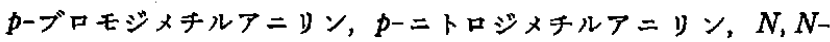
ジメチルーpーペンズアルデとドは市肘品を用い，再結晶あるいは 精留により精製して実験に供した。

反応溶媒の $N, N$-ジィチルホルムアミド (DMF) は，市版試薬 をシリカゲルで鞋嬠後，水素化カルシウムを加えて室素気流中減 圧下に精留（bp $76^{\circ} \mathrm{C} / 39 \mathrm{mmHg}$ ）して使用した。

\section{2 実験方法}

反応は $\mathrm{DMF}$ を溶媒とし，30〜60 ${ }^{\circ} \mathrm{C}$ の所定温度で別々に用意

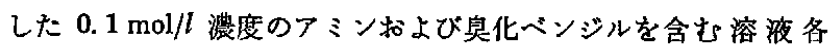
$25 \mathrm{~m} l$ を, 恒温槽中の反応器に加えて混合したのち，拣置したま ま反応させた。一定時閪ごとにシリンジを用いて反応液から $5 \mathrm{ml}$ を採取して，20 $\mathrm{m} l$ のベンゼン中に注ぎ反応を停止させるととも に, $10 \mathrm{ml}$ の純水で 5 回抽出した。抽出液中の臭化物イオンを硝 酸銀溶液を用いる電位差滴定法によって定冒し，反応の進行を追 跡した。

5) P. S. Radhakrishnamurti, G. P. Panigrahi, Bull. Chem. Soc. Jap., 43, 81(1970).

6) F. G. Bordwell, P. J. Boutan, J. Amer. Chem. Soc., 78, 89(1956).

7) H. Gilman, I. Banner, ibid., 62, 344(1940).

8) C. D. Hurd, C. N. Webb, "Organic Syntheses", Coll. Vol. I, p. 217(1941).

9) R. Q. Brewster, W. Schroeder, "Organic Syntheses", Coll. Vol. II, p. 574(1941). 
Table 1 Quaternization of substituted dimethylanilines with benzyl bromide in DMF

\begin{tabular}{|c|c|c|c|c|c|c|c|c|}
\hline \multirow{2}{*}{ Substituent } & \multicolumn{2}{|c|}{ Substituent constants ${ }^{a}$ ) } & \multicolumn{3}{|c|}{$k \times 10^{4}\left(l \cdot \mathrm{mol}^{-1} \cdot \mathrm{sec}^{-1}\right)$} & \multirow{2}{*}{$\begin{array}{c}E \\
\left(\mathrm{kcal}^{-}\right. \\
\left.\mathrm{mol}^{-1}\right)\end{array}$} & \multirow{2}{*}{$\begin{array}{l}-\Delta S^{*} \\
\text { (e. u. })\end{array}$} & \multirow{2}{*}{$p K_{a}^{e)}$} \\
\hline & $\sigma$ & $\left(a^{-}\right)$ & $30^{\circ} \mathrm{C}$ & $45^{\circ} \mathrm{C}$ & $60^{\circ} \mathrm{C}$ & & & \\
\hline$p-\mathrm{OCH}_{3}$ & -0.27 & - & 38.9 & 78.1 & 144 & 8.75 & 42.8 & 5.85 \\
\hline$m-\mathrm{CH}_{3}$ & -0.07 & - & 9.13 & 18.5 & 37.2 & 9.39 & 43.6 & 5.34 \\
\hline$m-\mathrm{OH}$ & 0.12 & - & 7.82 & 16.5 & 32.0 & 9.42 & 43.8 & - \\
\hline $\mathrm{H}$ & 0.00 & - & 6.18 & 13. 4 & 27.6 & 10.0 & 42.3 & 5.07 \\
\hline$p-\mathrm{NO}_{2}$ & 0.78 & (1.24) & 0.138 & 0.203 & 0.391 & 6.93 & 60.1 & 0.61 \\
\hline$m-\mathrm{NO}_{2}$ & 0.71 & - & 0.491 & 0.830 & 1.30 & 6.52 & 58.9 & 2.63 \\
\hline$p-\mathrm{SCN}$ & 0.52 & 一 & 0.605 & 1.06 & 1. 69 & 6.90 & 57.2 & - \\
\hline$p-\operatorname{CoC}_{6} \mathrm{H}_{5}$ & $\left.0.459^{b}\right)$ & $(0.86)^{d)}$ & 0.378 & 0.631 & 1. 19 & 7.65 & 55.7 & - \\
\hline$p-\mathrm{CHO}$ & $0.45^{e)}$ & (1. 13) & 0.368 & 0.585 & 1.07 & 7. 13 & 57.5 & - \\
\hline
\end{tabular}

a) D. H. McDaniel, H. C. Brown, J. Org. Chem., 23, 420(1958).

b) M. Charton, ibid., 28, 3121(1963).

c) E. E. Humffray, J. J. Ryan, J. T. Warren, Y. H. Yung, Chem.Commun., 1965, 610.

d) J. J. Ryan, A. A. Humffray, J.Chem. Soc., B, 1967, 1300.

e) M. M. Fickling, A. Fischer, B. R. Mann, J. Packer, J. Vaughan, J. Amer. Chem. Soc., 81, 4226(1959).

\section{3 結果と考寮}

\section{1 反応速度と活性化バラメーター}

逆反応や相の不均一性などがない場合、一般にメンシュトキン

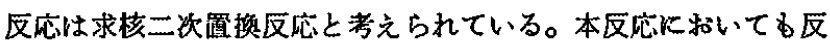
応時間 $t$ 亿対し $\log b(a-x) / a(b-x)$ をブロットすると，図1K みられる代表例のよらに直線関係を示し，二次反応速度式が適用 された。また溶媒们用いた DMF るハロゲン化アルキルと反応す ることが知られているが10，本反応では溶媒との反応はわずかで あり補正の必要は認めなかった。速度論的測定值は表 1 に揭げ

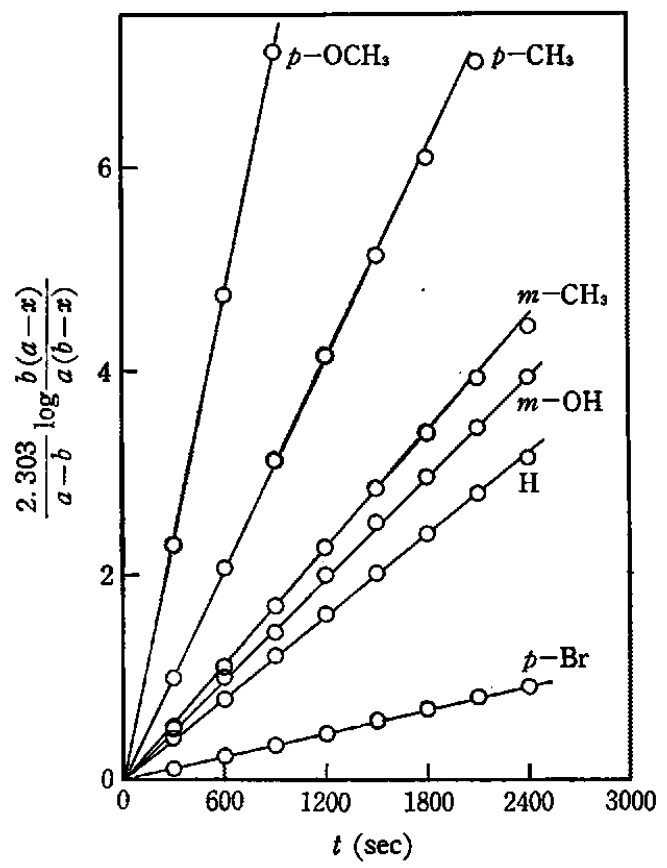

Fig. 1 The reaction of substituted dimethylanilines with benzyl bromide $\left(45^{\circ} \mathrm{C}\right)$

10) S. G. Smith, S. Winstein, Tetrahedron, 3, 317(1958); D. Djarov, A. Jovtscheff, Öster. Chem. Zeit., 1966, 319.
た。

置換ジメチルアニリンの四級化速度は置換基の電子供与性によ りいちじるしく促進され，一方，電子吸引性により阻害されるこ とを示している。活性化エネルギーEは $6.5 \sim 10 \mathrm{kcal} / \mathrm{mol} て$, DMF と注とんど等しい髅電率るるつニトロベンゼン中での置換 アニリン四級化 $\left.{ }^{5}\right) の E(7 〜 15 \mathrm{kcal} / \mathrm{mol})$ に注近い倠である。 た活性化エントロピーはこの種の反㐫において減少するのが一般 的事実として周知のことであるが，本反応の聂合 $\Delta S *$ は -42 〜 -60 e.u. であり，既報11の DMF 中での ピリジン四級化にく らべて小さいのが特暀的である。

等動力学的関係として知られる $E$ または $\Delta H^{*}$ と $\Delta S^{*}$ との関 係を因 2 に示した。

等動力学的関係はメンシュトキン反応和いてす成立する例が

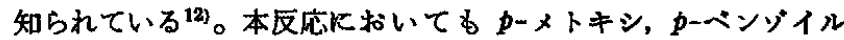
怙よび $p$-ニトロ基を除いて等動力学的関係が諰められ, Hammett

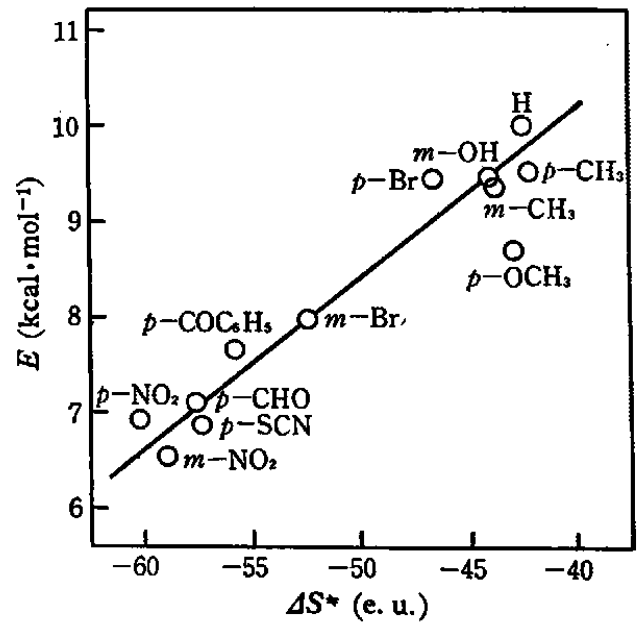

Fig. 2 Correlation between $E$ and $\Delta S^{*}$

11）村井幸一，本村 日化，90，503(1969).

12) J. E. Leffler, E. Grunwald, "Rate and Equilibria of Organic Reactions", John Wiley and Sons, Inc., New York, N. Y. (1963) p. 327. 


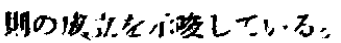

\subsection{Hammett 則蔺保}

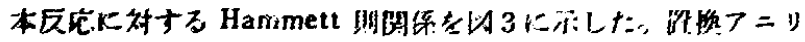

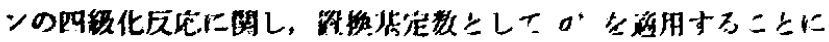

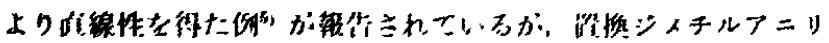

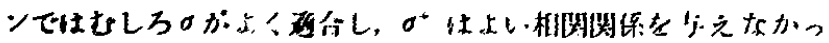

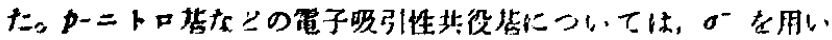

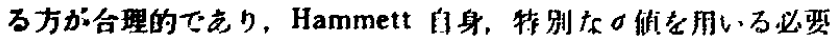

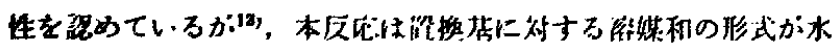

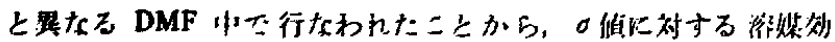

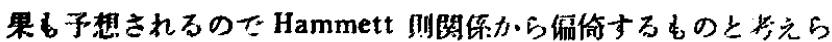

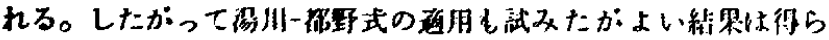
れなかった。

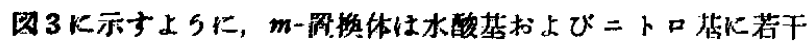

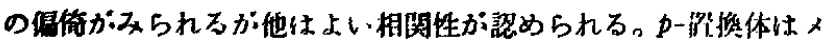
トキシ,ニトロおよびカルボニル基を含むホルミル, ベンッィル

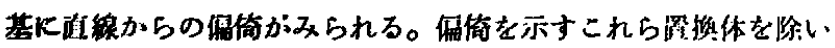

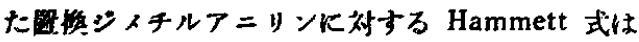

$$
\begin{aligned}
\log k & =-1.92 \sigma-2.874\left(45^{\circ} \mathrm{C}\right) \\
r & =0.989, r: \text { 相偻係数 }
\end{aligned}
$$

であらわされる。

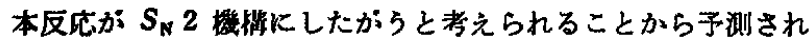

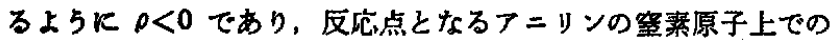
軍子密度の增加により反店は促 進される。反论定数 $\rho=-1.92$ は，報告されているニトロペンゼン中での臭化ベンジルと䀈換ア

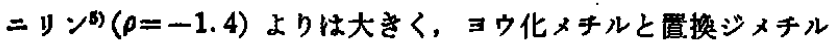

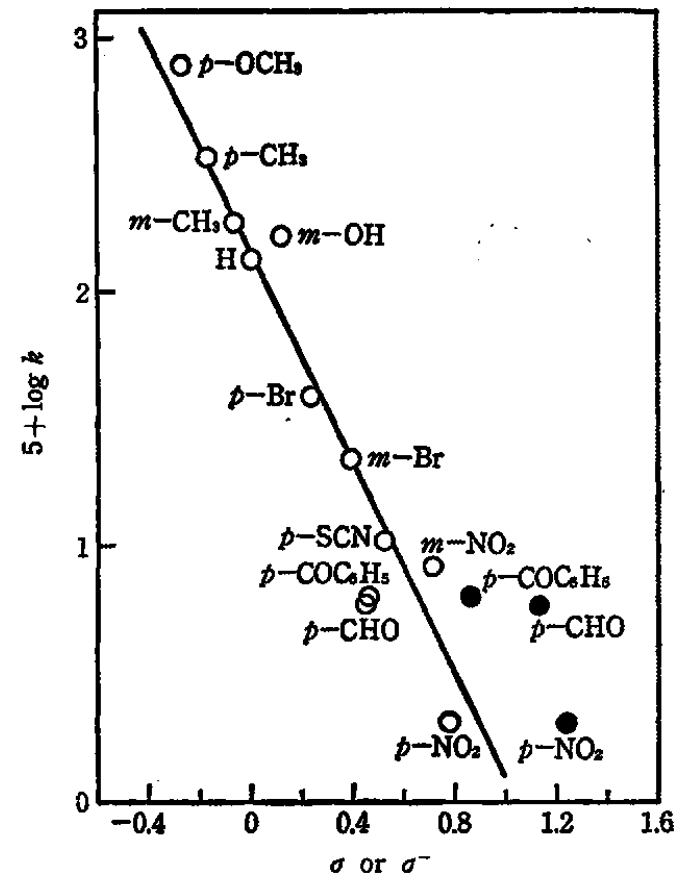

Fig. 3 Hammett plot for the reaction of substituted dimethylanilines with benzyl bromide

$$
0: \sigma, O: \sigma^{-}
$$

13) L. P. Hammett, "Physical Organic Chemistry", McGrawHill(1940) p. 184.

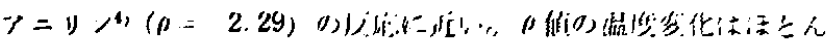

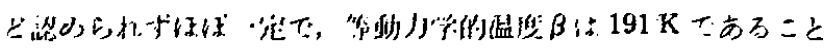

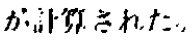

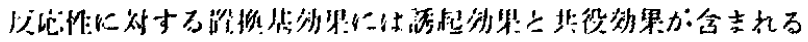

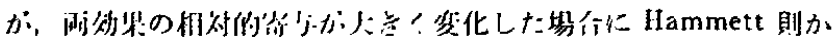

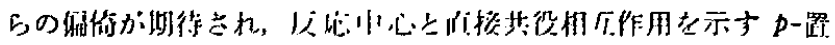

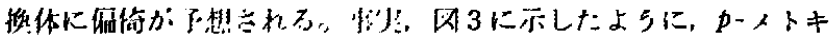

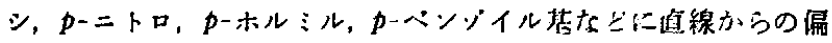

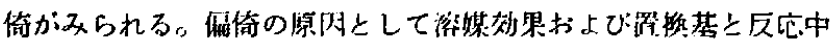

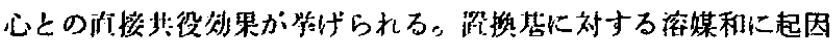

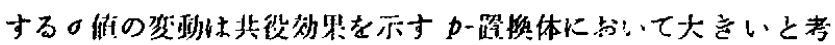

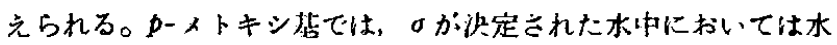
素結合のため電子供与性が弱められるのに付し，DMF 溶媒中で

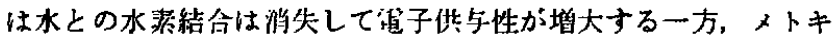
シ背と反応叶心との直接其役效果によりこの作用が助辰されて反 性が液められ，Hammett 式の直線の上方に傦倚するるのと考

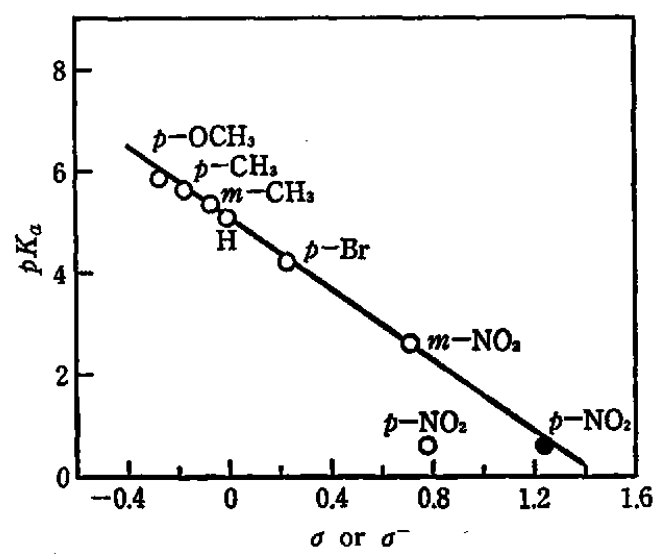

Fig. 4 Correlation between $\sigma$ or $\sigma^{-}$and $p K_{a}$ $\mathrm{O}: \sigma, \mathrm{O}: \sigma^{-}$

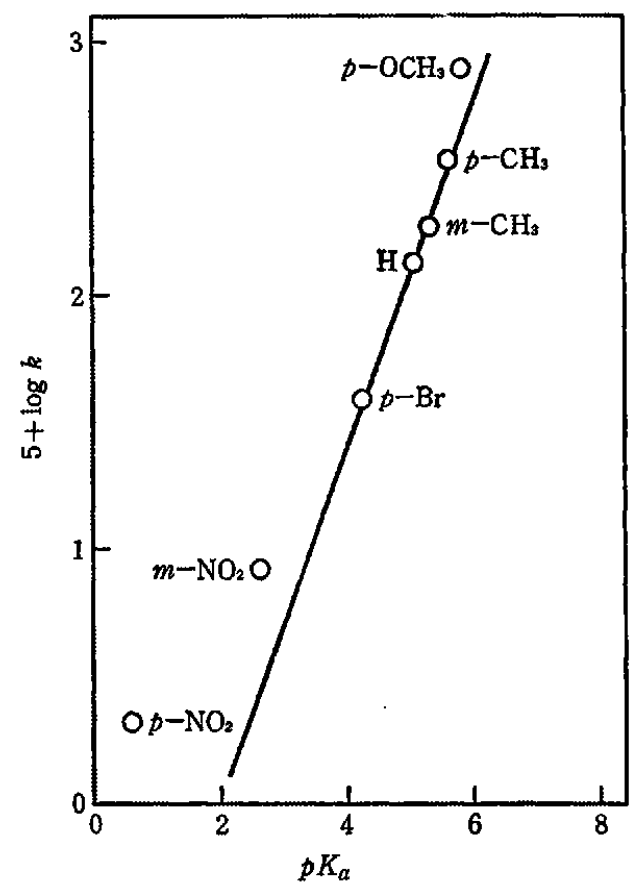

Fig. 5 Correlation between $p K_{a}$ and $\log k\left(45^{\circ} \mathrm{C}\right)$ 


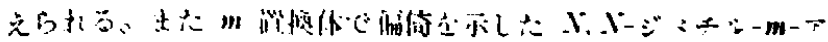

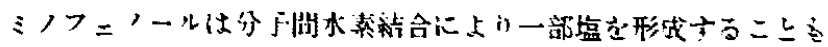

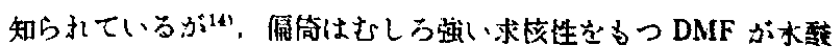

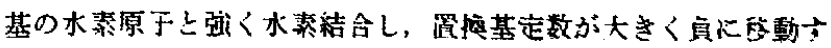

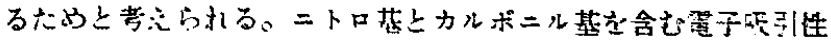

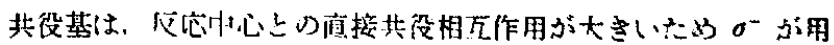
いられるが，DMF 巾ではメトキシ基り場合上同様な理由ふらす電

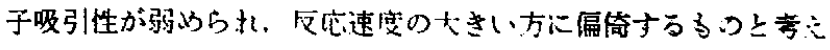
られる。

\section{3 解唯定数と反忘速度}

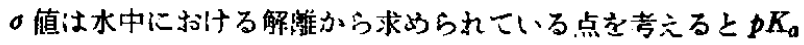
とのとの相関性が期待される。置換アニリンについ $p K_{a}$ と。

14) S. Patai ed., "The Chemistry of the Amino Group". Interscience Publishers (1968)p. 226.

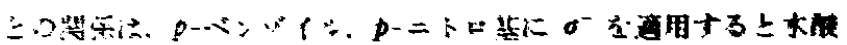

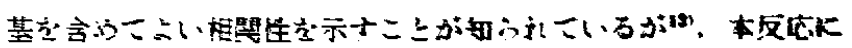

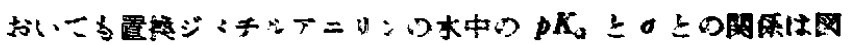
せに示なように、酒侉しこいる

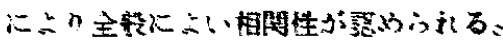

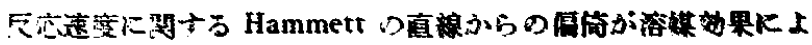

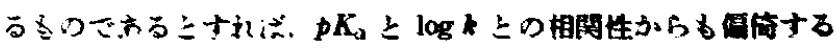

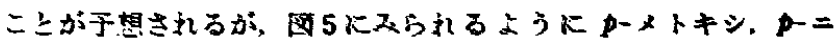

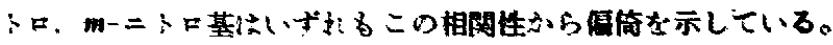

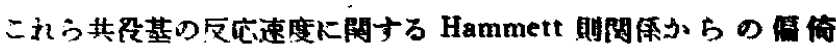

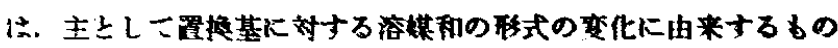
ごすこ上が推察される。

(1971 年9月. 日本化学会東北地力大会福济)

\section{The Quaternization of Substituted $N, N$-Dimethylanilines with Benzyl Bromide \\ Minoru Tsuruta*, Koichi Murai**, Takeshi Sato* and Chikai Kimura** \\ * Department of Industrial Chemistry, Akita Technical College: Iizima, Akita-shi, Japan \\ ** Department of Fuel Chemistry. Faculty of Mining, Akita University ; Tegata, Akita-shi, Japan}

The rates of quaternization of substituted $N, N$-dimethylanilines with benzyl bromide were measured at 30,45 and $60^{\circ} \mathrm{C}$ in dimetylformamide (DMF). The effect of substituents on the reactivity of dimethylaniline and the existence of linear free energy relationship were discussed.

The kinetic data are shown in Table 1. The rate constants $k$ are in the range $0.203 \sim 78.1 \times$ $10^{-4} l \cdot \mathrm{mol}^{-1} \cdot \mathrm{sec}^{-1}\left(45^{\circ} \mathrm{C}\right)$ and increase with the electron repelling ability of substituents. The values of the activation energy $\mathrm{E}$ are $6.5 \sim 10 \mathrm{kcal} / \mathrm{mol}$ and the activation entropy $\Delta S^{*}$ are $-42 \sim$ -60 e.u., and the isokinetic relationship is observed between them as shown in Fig. 2. Hammett equation using $\sigma$ as substituent constants is given by

$$
\log k=-1.92 \circ-2.874 \quad\left(45^{\circ} \mathrm{C}\right) \text {. }
$$

As shown in Fig. 3 the deviations from the Hammett correlation are found for $m$-dimethylaminophenol and $p$-substituted dimethylanilines substituted with formyl, benzoyl, nitro and methoxyl groups at $n$-position. The deviations are considered to be attributed to the conjugative interaction between the reaction center and these substituents and to the solvent effect of DMF on the substituent constants of these groups.

$\dagger$ Kinetic Studies on the Quaternization of Tertiary Amines. VII. 